\title{
SHORT-TERM IMPACT OF A HYDROELECTRIC POWER PLANT'S RESERVOIR ON THE TREE COMPONENT IN AN ECOTONAL AREA IN SANTA CATARINA ${ }^{1}$
}

Carla Luciane Lima ${ }^{2 *}$, Ana Carolina da Silva ${ }^{3}$, Pedro Higuchi ${ }^{3}$, Amanda da Silva Nunes ${ }^{2}$, Juliana Pizutti Dallabrida $^{2}$, Karina Montibeller da Silva ${ }^{4}$, Mariéle Alves Ferrer da Silva $^{2}$, Pâmela Niederauer Pompeo ${ }^{2}$, Vanessa Fatima Soboleski², Rodineli Loebens ${ }^{2}$, Aline Pereira $\mathrm{Cruz}^{2}$, Karine Souza ${ }^{2}$, Chayane Cristina de Souza $^{2}$ and Jéssica Oneda da Silva ${ }^{2}$

\footnotetext{
${ }^{1}$ Received on 03.03.2015 accepted for publication on 28.06.2017.

${ }^{2}$ Universidade do Estado de Santa Catarina, Programa de Pós-Graduação em Engenharia Florestal, Lages,SantaCatarina,Brasil.Email:<carla_engflorestal@yahoo.com.br $>,<$ amandaeng.f@gmail.com>, <juli_ajuri@hotmail.com $>,<$ mariele.ferrer@hotmail.com>, $<$ pamniederauer@gmail.com>,<vanessasoboleski@hotmail.com>, $>$ rhodineli@hotmail.com>,<a.line_cruz@yahoo.com.br $>$, $<$ karisouza@hotmail.com>,<chayanesouza8@gmail.com>and <jessica.oneda@hotmail.com.br>.

${ }^{3}$ Universidade do Estado de Santa Catarina, Departamento em engenharia Florestal, Lages, Santa Catarina, Brasil. E-mail: <carol_sil4@yahoo.com.br>and <higuchip@gmail.com>.

${ }^{4}$ Universidade do Estado de Santa Catarina, Programa de Pós-Graduação em Produção Vegetal, Santa Catarina, Brasil. Email: <karynaflorestal@yahoo.com.br>.

*Corresponding author.
}

\begin{abstract}
This study was conducted in an ecotonal area between the Mixed Ombrophilous Forest (MOF) and the Deciduous Seasonal Forest (DSF) in Santa Catarina, Brazil, to identify the impact of the water reservoir of the Garibaldi hydroelectric power plant on the mortality and floristic-structural composition of the tree component in a riparian forest adjacent to it. One year after the reservoir water filling, $48200 \mathrm{~m}^{2}$ plots were systematically allocated in three sectors: adjacent to the water reservoir, intermediate slope and upper slope. The tree species individuals with circumference at breast height $(\mathrm{CBH}) \geq 15.7 \mathrm{~cm}$ were identified and measured $(\mathrm{CBH})$; dead individuals were quantified. The geographic coordinates of each plot were obtained. Species diversity was analyzed by Shannon and Pielou indexes and the floristic-structural organization was evaluated through phytosociological estimates, Non-Metric Multidimensional Scaling (NMDS) and Mantel test. Variations on mortality and floristic-structural organization regarding environmental sectors were tested with Generalized Linear Models (GLMs). 70 species have been found in the community with Shannon and Pielou values of 3.10 and 0.73 , respectively. Dead individuals have shown the second highest importance value $(9.59 \%)$ with the highest mortality in the lower sector $(p<0.05)$, which may be associated with its proximity to the water surface. The community organization has shown spatial structure; however, the NMDS and GLMs have shown no floristic-structural differentiation among sectors, probably on account of the short period of exposure to reservoir filling impacts.
\end{abstract}

Keywords: Environmental Impacts; Mixed Ombrophilous Forest; Deciduous Seasonal Forest.

\section{IMPACTO EM CURTO PRAZO DO RESERVATÓRIO DE UMA UHE SOBREO COMPONENTE ARBÓREO EM ÁREA ECOTONAL EM SANTA CATARINA}

RESUMO - O estudo foi realizado em uma área ecotonal entre Floresta Ombrófila Mista e Floresta Estacional Decidual em Santa Catarina, objetivando identificar o impacto do enchimento do reservatório da UHE Garibaldi na mortalidade e composição florístico-estrutural da floresta ciliar adjacente às margens do lago. Um ano 


\begin{abstract}
após o enchimento do reservatório, foram alocadas 48 parcelas de $200 \mathrm{~m}^{2}$ cada, de forma estratificadasistemática, em três setores do fragmento: adjacente às margens do reservatório, meio da encosta e topo da encosta. Os indivíduos arbóreos nas parcelas com circunferência a altura do peito (CAP) e" $15,7 \mathrm{~cm}$ foram identificados e mensurados (CAP), sendo os mortos quantificados. Foram obtidas as coordenadas geográficas de cada parcela. A diversidade foi analisada pelos índices de Shannon e Pielou. A organização florística-estrutural foi avaliada pelas estimativas fitossociológicas, Escalonamento Multidimensional NãoMétrico (NMDS) e teste de Mantel. As variações da mortalidade e da organização florística-estrutural em função dos setores ambientais foi testada por Modelos Lineares Generalizados (GLMs). Na comunidade foram encontradas 70 espécies, com os valores dos índices de Shannon e Pielou, respectivamente, de 3,10 e 0,73. Os indivíduos mortos obtiveram o segundo maior valor de importância (9,59\%), com maior mortalidade no setor inferior ( $\mathrm{p}<0,05)$, o que pode estar associada à maior proximidade com a lâmina d'água. Houve estruturação espacial na organização da comunidade, porém, a NMDS e modelos GLMs não indicaram diferenciação florístico-estrutural entre os setores, provavelmente devido ao curto período de exposição aos impactos do enchimento do reservatório.
\end{abstract}

Palavras-Chave: Impacto ambiental; Floresta Ombrófila Mista; Floresta Estacional Decidual.

\section{INTRODUCTION}

The Atlantic Forest biome is known as a hotspot due to its great diversity of species and high proportion of endemic and endangered species (Myers et al., 2000). The state of Santa Catarina is located in this biome, with Ombrophilous formation at east and Deciduous formation at west. The area under study is located in a transition region between the Mixed Ombrophilous Forest (MOF) and the Deciduous Seasonal Forest (DSF), in the Upper Uruguay River basin, with high hydroelectric potential. Hydroelectric power plants (HPP) have been therefore built along its rivers, suppressing vegetation and reducing forest areas.

Their construction mainly affects riparian forests by causing the reduction and, sometimes, the disappearance of plant and animal species (Fearnside, 2001). By elevating the river's level and establishing the reservoir, new riparian forests are formed due to the water level fluctuation that causes a higher soil waterlogging of part of the vegetation that used to be distant from the water course, resulting in the selection of species adapted to this new environmental condition. These reservoir riparian environments are unique places ranging from mesic sites free from flooding to depletion areas where plants are partially or totally submerged during flood period (Davide et al., 1996). The seasonal change of aquatic/terrestrial habitats along the year creates stress over the plants, demanding them to adapt for surviving to long periods of submersion (Junk, 1989). Changing the species potentially able to colonize the reservoir banks afterwards might cause significant changes in the floristic-structural composition of remnant fragments (Ferreira et al., 2013).

This study aimed to identify the impact of filling the reservoir of the Garibaldi hydroelectric power plant on the floristic-structural composition of the riparian forest adjacent to the lake banks one year after the filling. Three sectors have been defined for the forest: the first one near the lake banks and the other two along the slope. As a hypothesis, the forest in the sector adjacent to the lake banks was expected to show higher tree mortality than the other two sectors since it is more influenced by water flooding. In addition, the highest number of dead trees on the reservoir banks was expected to result in the floristic-structural variation among sectors, a process that would represent the beginning of species substitution with the exit of those not tolerant to water stress.

\section{MATERIALAND METHODS}

The study was carried out in a forest remnant located in the municipality of São José do Cerrito, SC, Brazil, in an area of the Garibaldi hydroelectric power plant reservoir built in 2013. It is placed in the Canoas River basin at $27^{\circ} 55^{\prime} 73^{\prime \prime}$ 'South latitude and $50^{\circ} 95^{\prime} 60^{\prime \prime}$ 'West longitude and from 700 to $800 \mathrm{~m}$ altitude with wavy to rugged topography.

According to Köppen's classification, it has a Cfb regional climate: mesothermic humid with a mild summer. Its mean annual temperature ranges from 15.8 to $17.9^{\circ} \mathrm{C}$ with annual rainfall ranging from 1,460 to $1,820 \mathrm{~mm}$ (EPAGRI, 1999). IBGE (2012) classifies it as Mixed Ombrophilous Forest (MOF) in transition with Deciduous Seasonal Forest (DSF). The area is in advanced

Revista Árvore. 2017;41(3):e410317

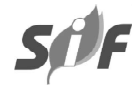


successional stage, showing great specimens of the region's flora. Its current state of conservation is a result of the low exploitation of timber species in the forest remnant opted by its owner in the past and of the recently acquisition of part of the area by the company responsible for the Garibaldi hydroelectric power plant to compose the Permanent Preservation Area (PPA) of the lake. It is mainly formed by haplic Nitosols and humic Cambisols soils developed from basaltic rocks (Embrapa, 2004).

By August, 2014, one year after the reservoir filling, $48200 \mathrm{~m}^{2}(10 \times 20 \mathrm{~m})$ permanent plots were systematically allocated $20 \mathrm{~m}$ apart from each other and $30 \mathrm{~m}$ from sector to sector (Figure 1): adjacent to the reservoir banks or lower sector (S1), in the middle of the slope or intermediate sector (S2) and at the top of the slope or upper sector (S3). All tree individuals with circumference at breast height $(\mathrm{CBH}) \geq 15.7 \mathrm{~cm}$ were then measured, tagged and identified. Standing dead individuals were also measured and quantified. Identification was held by comparing herbaria and specialized literature; families were classified according to the APG III system (2009). Spatial variables corresponding to the $\mathrm{x}$ and $\mathrm{y}$ coordinates of each plot's center were obtained through GPS.

Sampling sufficiency was analyzed by the species accumulation curve through the randomization method with 1,000 permutations. Diversity and evenness were verified by Shannon and Pielou indexes, respectively (Brower and Zar, 1984). Tree component floristic-structural composition was evaluated according to the classic phytosociological estimates (Mueller-Dombois and Ellenberg, 1974).

The graphical representation of the variation of the number of dead individuals per plot in each sector was carried out by a box-plot graph. In order to verify if there was significant difference in the number of dead trees among sectors, a Generalized Linear Model (GLM) was applied with the Poisson distribution by considering each sector as a categorical explanatory variable. Because data variance is higher than the mean therefore resulting in overdispersion, standard errors were corrected through a quasi-GLM model, where variance is given by $\varphi \times \mu$, where $\mu$ is the mean and $\varphi$ is the parameter of dispersion (Zuur et al., 2009). The Mantel test was applied to determine whether or not the floristic-structural organization had spatial structure. The community's floristic-structural ordination was performed through the Non-Metric Multidimensional Scaling (NMDS). Generalized linear models were adjusted according to the methodology proposed by Wang et al. (2012) with species abundances as dependent variables and sectors as independent variables to verify the existence of floristic-structural variations among sectors. The negative binomial distribution was considered for the models since many species have just a few individuals. The species matrix of abundance per plot underwent a Hellinger transformation for reducing asymmetry among the most abundant and rare species (Legendre and Legendre, 2012). The suitability of all adjusted models was verified through the graphic analysis of the residues in order to verify the normality and heteroskedasticity of their distributions.

All analyzes were performed with the $\mathrm{R}$ statistical programming language ( $\mathrm{R}$ Development Core Team, 2014) by using the vegan package (Oksanen et al., 2014) for the species accumulation curve, Mantel test and NMDS; and the mvabund package (Wang et al., 2014) for adjusting the generalized linear models.

\section{RESULTS}

A total of 1,505.21 ind.ha ${ }^{-1}$ have been registered, which represent $30,60 \mathrm{~m}^{2}$.ha $\mathrm{a}^{-1}$ basal area. By excluding the dead individuals basal area $\left(3,772 \mathrm{~m}^{2} \cdot \mathrm{ha}^{-1}\right)$, the basal area value has reduced to $26,828 \mathrm{~m}^{2} \cdot \mathrm{ha}^{-1}$. Sampled individuals are distributed in 70 tree species, 56 genera and 32 botanical families (Table 1). Nine individuals from two genera have been identified only at the gender level. In addition, 14 individuals have not been identified due to leafless. The highest species richness have been found in the families Myrtaceae (nine), Fabaceae (nine), Lauraceae (six), Sapindaceae (four) and Salicaceae (four). The highest genera richness have been found among the genera Eugenia (four), Casearia (three), Ocotea (three), Solanum (three), Allophylus (two), Annona (two), Campomanesia (two), Nectandra (two) and Zanthoxylum (two).

According to the species accumulation curve, species richness has increased only $1.24 \%$ by including the last five plots ( $10 \%$ of the sampled area). Diversity and equability have reached the following values: $H^{\prime}=$ 3.10 and $\mathrm{J}^{\prime}=0.73$.

The highest importance values (IV) have been found in the species Allophylus edulis (A.St.-Hil. et 


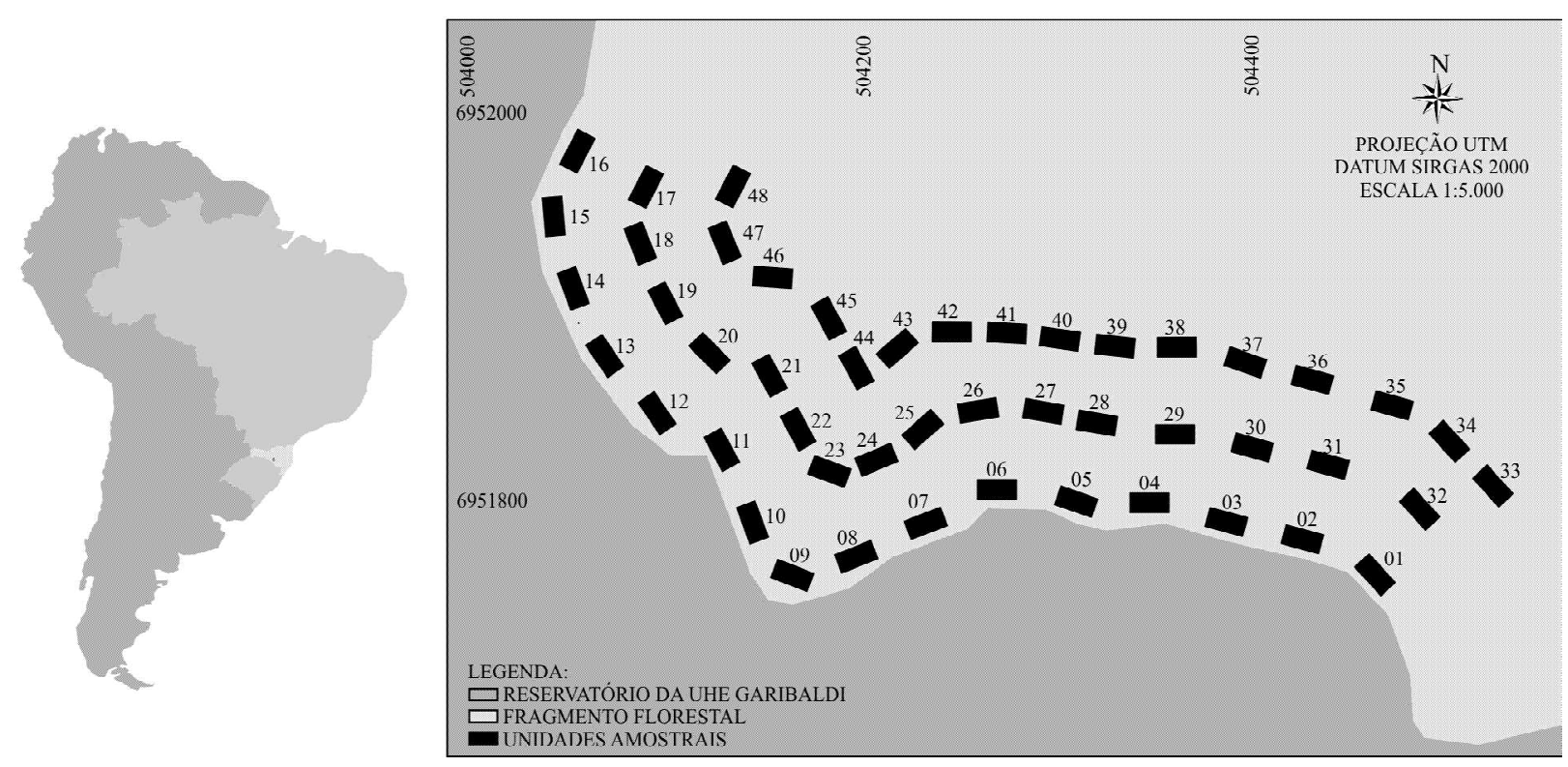

Figure 1-Location of sampling units in the riparian forest area in the municipality of São José do Cerrito, SC, Brazil. Plots from 1 to 16 are in the lower sector, from 17 to 32 in the intermediate sector and from 33 to 48 in the upper sector.

Figura 1 - Localização das unidades amostrais no trecho de floresta ciliar avaliado em São José do Cerrito, SC. Parcelas de 1 a 16 estão no setor inferior, de 17 a 32 no setor intermediário e de 33 a 48 no setor superior.

al.) Hieron. ex Niederl. (12.70\%), dead individuals (9.59\%), Nectandra megapotamica (Spreng.) Mez (7.94\%), Araucaria angustifolia (Bertol.) Kuntze (7.67\%), Styrax leprosus Hook. \& Arn. (6.05\%) and Cupania vernalis Cambess. (5.01\%). The IV value of the 10 most important species has summed $62.93 \%$. Thus, two-thirds of the tree species' importance belong to only $13.89 \%$ of registered species. Twelve from all registered species have been classified as rare, with only one occurrence in the sampling area each.

We highlight the high density (152.08 ind.ha-1), dominance $\left(3,772 \mathrm{~m}^{2} \cdot \mathrm{ha}^{-1}\right)$ and absolute frequency (77.08\%) of dead individuals, therefore ranking second in IV. The dead trees number was relatively high (146 individuals) with the highest value in the lower sector (81), which is closer to the reservoir and, consequently, to a soil more soaked, followed by the intermediate (39) and upper (26) sectors. The numerical variation of the dead trees among the three sectors (Figure 2) has resulted in a significant difference $(p=0.002)$ with the lower sector differing from the other two ( $p=0.024$ in comparison with the intermediate sector and $p=$ 0.003 in comparison with the upper sector).
The Mantel test has resulted in $\mathrm{r}=0.2997(p=0.001)$ thus indicating spatial structuring in the community organization. The NMDS ordering diagram (Figure 3) has indicated no variation in the floristic-structural composition among the three sectors, which has been confirmed by the mvabund function $(p=0,371)$.

\section{DISCUSSION}

The basal area value we have found $\left(26.828 \mathrm{~m}^{2} \cdot \mathrm{ha}^{-1}\right.$ excluding dead individuals) is below from what is expected in this region for forest areas in advanced successional stages. Such value is lower than what have been observed both in MOF areas by Herrera et al. (2009) $\left(31.4 \mathrm{~m}^{2} \cdot \mathrm{ha}^{-1}\right)$, Higuchi et al. (2012) (36.45 $\mathrm{m}^{2}$.ha-1), Silva et al. (2012) (35.54 $\left.\mathrm{m}^{2} \cdot \mathrm{ha}^{-1}\right)$ and Higuchi et al. (2013) $\left(34.8 \mathrm{~m}^{2} \cdot \mathrm{ha}^{-1}\right)$ and in MOF and DSF transition areas by Souza et al. (2015) $\left(32.32 \mathrm{~m}^{2} \cdot \mathrm{ha}^{-1}\right)$. Results thus suggest the impact of the hydroelectric power plant's lake on the forest structure.

Species and families richness registered for the area under study can be considered as intermediate in relation to other studies carried out in the same region. Jarenkow and Budke (2009) have compiled and analyzed the floristic and structural patterns of studies related to 38 areas carried out by several authors in the Mixed

Revista Árvore. 2017;41(3):e410317 
Table 1 - Floristic-Structural composition of a forest remnant from an ecotonal area between Mixed Ombrophilous Forest and Deciduous Seasonal Forest, in the municipality of São José do Cerrito, SC, Brazil, ranked by importance value $(\mathrm{IV}, \%)\left[\mathrm{AD}=\right.$ absolute density $\left(\right.$ ind $\left.\mathrm{ha}^{-1}\right) ; \mathrm{RD}=$ relative density $(\%) ;$ Ado $=$ absolute dominance $\left(\mathrm{m}^{2} . \mathrm{ha}^{-1}\right) ; \mathrm{RDo}$ $=$ relative dominance $(\%) ; \mathrm{AF}=$ absolute frequency $(\%) ; \mathrm{RF}=$ relative frequency $(\%)]$.

Tabela 1 - Composição florístico-estrutural de um remanescente florestal localizado em área de transição entre Floresta Ombrófila Mista e Floresta Estacional Decidual em São José do Cerrito, SC, classificados por seu Valor de Importância $\left(V I\right.$, em \%) $\left[D A=\right.$ densidade absoluta (ind. $\left.h a^{-1}\right) ; D R=$ densidade relativa $(\%) ; D o A=$ dominância absoluta $\left(\mathrm{m}^{2} . h a^{-1}\right)$; $D o R=$ dominância relativa (\%); $F A=$ frequência absoluta $(\%) ; F R=$ frequência relativa $(\%)]$.

\begin{tabular}{|c|c|c|c|c|c|c|c|}
\hline Species & $\mathrm{AD}$ & $\mathrm{RD}$ & ADo & RDo & $\mathrm{AF}$ & RF & IV \\
\hline $\begin{array}{l}\text { Allophylus edulis (A.St.-Hil. } \\
\text { et al.) Hieron. ex Niederl. }\end{array}$ & 331.25 & 22.01 & 2.675 & 8.74 & 89.58 & 7.36 & 12.70 \\
\hline Dead trees & 152.08 & 10.10 & 3.772 & 12.33 & 77.08 & 6.34 & 9.59 \\
\hline Nectandra megapotamica (Spreng.) Mez & 128.13 & 8.51 & 2.747 & 8.98 & 77.08 & 6.34 & 7.94 \\
\hline Araucaria angustifolia (Bertol.) Kuntze & 91.67 & 6.09 & 3.496 & 11.43 & 66.67 & 5.48 & 7.67 \\
\hline Styrax leprosus Hook. \& Arn. & 138.54 & 9.20 & 1.581 & 5.17 & 45.83 & 3.77 & 6.05 \\
\hline Cupania vernalis Cambess. & 67.71 & 4.50 & 1.654 & 5.41 & 62.50 & 5.14 & 5.01 \\
\hline Gymnanthes klotzschiana Müll.Arg. & 56.25 & 3.74 & 1.664 & 5.44 & 58.33 & 4.79 & 4.66 \\
\hline Casearia decandra Jacq. & 64.58 & 4.29 & 0.705 & 2.30 & 60.42 & 4.97 & 3.85 \\
\hline Ocotea puberula (Rich.) Nees & 10.42 & 0.69 & 2.029 & 6.63 & 18.75 & 1.54 & 2.95 \\
\hline Cedrela fissilis Vell. & 17.71 & 1.18 & 1.258 & 4.11 & 27.08 & 2.23 & 2.50 \\
\hline Lonchocarpus campestris Mart. ex Benth. & 35.42 & 2.35 & 0.661 & 2.16 & 33.33 & 2.74 & 2.42 \\
\hline Luehea divaricata Mart. \& Zucc. & 22.92 & 1.52 & 0.964 & 3.15 & 31.25 & 2.57 & 2.41 \\
\hline Nectandra lanceolata Nees & 12.50 & 0.83 & 1.246 & 4.07 & 18.75 & 1.54 & 2.15 \\
\hline Zanthoxylum rhoifolium Lam. & 22.92 & 1.52 & 0.527 & 1.72 & 27.08 & 2.23 & 1.82 \\
\hline Annona rugulosa (Schltdl.) H.Rainer & 25.00 & 1.66 & 0.172 & 0.56 & 37.50 & 3.08 & 1.77 \\
\hline Ocotea pulchella (Nees \& Mart.) Mez & 27.08 & 1.80 & 0.466 & 1.52 & 22.92 & 1.88 & 1.74 \\
\hline Erythroxylum deciduum A.St.-Hil. & 20.83 & 1.38 & 0.479 & 1.56 & 27.08 & 2.23 & 1.72 \\
\hline Parapiptadenia rigida (Benth.) Brenan & 15.63 & 1.04 & 0.461 & 1.51 & 27.08 & 2.23 & 1.59 \\
\hline Indivíduos não identificados & 14.58 & 0.97 & 0.366 & 1.20 & 27.08 & 2.23 & 1.46 \\
\hline Sapium glandulosum (L.) Morong & 14.58 & 0.97 & 0.493 & 1.61 & 20.83 & 1.71 & 1.43 \\
\hline $\begin{array}{l}\text { Campomanesia xanthocarpa } \\
\text { (Mart.) O.Berg }\end{array}$ & 12.50 & 0.83 & 0.099 & 0.32 & 22.92 & 1.88 & 1.01 \\
\hline Mimosa scabrella Benth. & 20.83 & 1.38 & 0.117 & 0.38 & 12.50 & 1.03 & 0.93 \\
\hline Eugenia pyriformis Cambess. & 9.38 & 0.62 & 0.125 & 0.41 & 18.75 & 1.54 & 0.86 \\
\hline Prunus myrtifolia (L.) Urb. & 7.29 & 0.48 & 0.249 & 0.81 & 12.50 & 1.03 & 0.77 \\
\hline Matayba elaeagnoides Radlk. & 8.33 & 0.55 & 0.135 & 0.44 & 14.58 & 1.20 & 0.73 \\
\hline Eugenia subterminalis DC. & 8.33 & 0.55 & 0.106 & 0.35 & 14.58 & 1.20 & 0.70 \\
\hline Ocotea diospyrifolia (Meisn.) Mez & 9.38 & 0.62 & 0.084 & 0.28 & 14.58 & 1.20 & 0.70 \\
\hline Strychnos brasiliensis Mart. & 9.38 & 0.62 & 0.058 & 0.19 & 12.50 & 1.03 & 0.61 \\
\hline Casearia sylvestris Sw. & 8.33 & 0.55 & 0.078 & 0.26 & 12.50 & 1.03 & 0.61 \\
\hline Eugenia uniflora L. & 7.29 & 0.48 & 0.059 & 0.19 & 12.50 & 1.03 & 0.57 \\
\hline Inga virescens Benth. & 6.25 & 0.42 & 0.126 & 0.41 & 10.42 & 0.86 & 0.56 \\
\hline Machaerium paraguariense Hassl. & 7.29 & 0.48 & 0.098 & 0.32 & 10.42 & 0.86 & 0.55 \\
\hline Banara tomentosa $\mathrm{Clos}$ & 8.33 & 0.55 & 0.048 & 0.16 & 10.42 & 0.86 & 0.52 \\
\hline Casearia obliqua Spreng. & 5.21 & 0.35 & 0.142 & 0.46 & 8.33 & 0.68 & 0.50 \\
\hline Sebastiania brasiliensis Spreng. & 6.25 & 0.42 & 0.067 & 0.22 & 10.42 & 0.86 & 0.50 \\
\hline Eugenia involucrata DC. & 5.21 & 0.35 & 0.087 & 0.28 & 10.42 & 0.86 & 0.50 \\
\hline Randia ferox (Cham. \& Schltdl.) DC. & 6.25 & 0.42 & 0.108 & 0.35 & 8.33 & 0.68 & 0.48 \\
\hline $\begin{array}{l}\text { Allophylus guaraniticus (A. } \\
\text { St.-Hil.) Radlk. }\end{array}$ & 7.29 & 0.48 & 0.028 & 0.09 & 10.42 & 0.86 & 0.48 \\
\hline Annona sylvatica A.St.-Hil. & 4.17 & 0.28 & 0.118 & 0.39 & 8.33 & 0.68 & 0.45 \\
\hline Dalbergia frutescens (Vell.) Britton & 6.25 & 0.42 & 0.020 & 0.07 & 10.42 & 0.86 & 0.45 \\
\hline Cryptocarya aschersoniana $\mathrm{Mez}$ & 2.08 & 0.14 & 0.241 & 0.79 & 4.17 & 0.34 & 0.42 \\
\hline Piptocarpha angustifolia & 6.25 & 0.42 & 0.073 & 0.24 & 6.25 & 0.51 & 0.39 \\
\hline Dusén ex Malme & 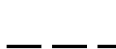 & 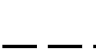 & & & & & \\
\hline
\end{tabular}


Table 1...

Tabela 1...

\begin{tabular}{|c|c|c|c|c|c|c|c|}
\hline & & & & & & & \\
\hline Bauhinia forficata Link & 5.21 & 0.35 & 0.017 & 0.05 & 8.33 & 0.68 & 0.36 \\
\hline $\begin{array}{l}\text { Campomanesia guazumifolia } \\
\text { (Cambess.) O.Berg }\end{array}$ & 5.21 & 0.35 & 0.047 & 0.15 & 6.25 & 0.51 & 0.34 \\
\hline $\begin{array}{l}\text { Myrsine coriacea (Sw.) R.Br. } \\
\text { ex Roem. \& Schult. }\end{array}$ & 2.08 & 0.14 & 0.085 & 0.28 & 4.17 & 0.34 & 0.25 \\
\hline Maytenus aquifolia Mart. & 3.13 & 0.21 & 0.011 & 0.03 & 6.25 & 0.51 & 0.25 \\
\hline Vitex megapotamica (Spreng.) Moldenke & 2.08 & 0.14 & 0.080 & 0.26 & 4.17 & 0.34 & 0.25 \\
\hline $\begin{array}{l}\text { Senegalia bonariensis (Gillies } \\
\text { ex Hook. \& Arn.) Seigler \& Ebinger }\end{array}$ & 5.21 & 0.35 & 0.014 & 0.05 & 4.17 & 0.34 & 0.25 \\
\hline Cinnamodendron dinisii Schwacke & 3.13 & 0.21 & 0.039 & 0.13 & 4.17 & 0.34 & 0.23 \\
\hline Lamanonia ternata Vell. & 2.08 & 0.14 & 0.056 & 0.18 & 4.17 & 0.34 & 0.22 \\
\hline Phytolacca dioica L. & 1.04 & 0.07 & 0.122 & 0.40 & 2.08 & 0.17 & 0.21 \\
\hline Lithrea brasiliensis Marchand & 2.08 & 0.14 & 0.044 & 0.15 & 4.17 & 0.34 & 0.21 \\
\hline Acca sellowiana (O.Berg) Burret & 2.08 & 0.14 & 0.044 & 0.14 & 4.17 & 0.34 & 0.21 \\
\hline Solanum sanctae-catharinae Dunal & 2.08 & 0.14 & 0.042 & 0.14 & 4.17 & 0.34 & 0.21 \\
\hline Dasyphyllum spinescens (Less.) Cabrera & 2.08 & 0.14 & 0.041 & 0.13 & 4.17 & 0.34 & 0.20 \\
\hline Schinus terebinthifolius Raddi & 3.13 & 0.21 & 0.015 & 0.05 & 4.17 & 0.34 & 0.20 \\
\hline Myrocarpus frondosus Allemão & 3.13 & 0.21 & 0.012 & 0.04 & 4.17 & 0.34 & 0.20 \\
\hline Aspidosperma australe Müll.Arg. & 2.08 & 0.14 & 0.026 & 0.09 & 4.17 & 0.34 & 0.19 \\
\hline Dicksonia sellowiana Hook. & 2.08 & 0.14 & 0.077 & 0.25 & 2.08 & 0.17 & 0.19 \\
\hline Zanthoxylum petiolare A.St.-Hil. \& Tul. & 2.08 & 0.14 & 0.008 & 0.03 & 4.17 & 0.34 & 0.17 \\
\hline Clethra scabra Pers. & 1.04 & 0.07 & 0.044 & 0.14 & 2.08 & 0.17 & 0.13 \\
\hline Vernonanthura discolor (Spreng.) H.Rob. & 1.04 & 0.07 & 0.035 & 0.12 & 2.08 & 0.17 & 0.12 \\
\hline Solanum compressum L.B.Sm. \& Downs & 2.08 & 0.14 & 0.009 & 0.03 & 2.08 & 0.17 & 0.11 \\
\hline Alsophila setosa Kaulf. & 1.04 & 0.07 & 0.013 & 0.04 & 2.08 & 0.17 & 0.09 \\
\hline Baccharis semiserrata DC. & 1.04 & 0.07 & 0.008 & 0.03 & 2.08 & 0.17 & 0.09 \\
\hline $\begin{array}{l}\text { Myrcianthes gigantea } \\
\text { (D.Legrand) D.Legrand }\end{array}$ & 1.04 & 0.07 & 0.008 & 0.02 & 2.08 & 0.17 & 0.09 \\
\hline Solanum mauritianum Scop. & 1.04 & 0.07 & 0.005 & 0.01 & 2.08 & 0.17 & 0.09 \\
\hline Helietta apiculata Benth. & 1.04 & 0.07 & 0.004 & 0.01 & 2.08 & 0.17 & 0.08 \\
\hline $\begin{array}{l}\text { Actinostemon concolor } \\
\text { (Spreng.) Müll.Arg. }\end{array}$ & 1.04 & 0.07 & 0.003 & 0.01 & 2.08 & 0.17 & 0.08 \\
\hline Eugenia sp. & 1.04 & 0.07 & 0.003 & 0.01 & 2.08 & 0.17 & 0.08 \\
\hline Sambucus australis Cham. \& Schltdl. & 1.04 & 0.07 & 0.002 & 0.01 & 2.08 & 0.17 & 0.08 \\
\hline Citronella paniculata (Mart.) & 1.04 & 0.07 & 0.002 & 0.01 & 2.08 & 0.17 & 0.08 \\
\hline$\underline{\text { R.A.Howard }}$ & & & & & & & \\
\hline Total & 1505.21 & 100.00 & 30.60 & 100.00 & - & 100.00 & 100.00 \\
\hline
\end{tabular}

Ombrophylous Forest of south and southeastern Brazil and observed that species richness has ranged from 23 to 127 sampled species. By studying the composition, structure and floristic relations of the tree component in a seasonal forest in the municipality of Vale do Sol, Rio Grande do Sul, Brazil, Jarenkow and Waechter (2001) found a lower richness value for this phytophysiognomy: 55 species distributed in 46 genera and 23 families. In a transitional area between MOF and DSF, Souza et al. (2015) observed a richness (63 species) similar to what we have found.

The richest families we have registered are in agreement with other studies carried out in the region under study, such as Herrera et al. (2009) and Klauberg et al. (2010), where the highest richness have been observed in the families Myrtaceae and Lauraceae. The majority of rich families found by Souza et al. (2015) in a transitional area, excepting Rutaceae, have shown a close number: Myrtaceae (11), Rutaceae (6), Fabaceae (5), Lauraceae (4), and Sapindaceae (4). Results show that the floristics of the area is as expected for such region despite structural changes.

Species accumulation curve demonstrated that sampling effort was sufficient for the floristic characterization since it tended to stability and species have increased less than $5 \%$ after $10 \%$ increase in sampling area. According to the criteria of Kersten

Revista Árvore. 2017;41(3):e410317 


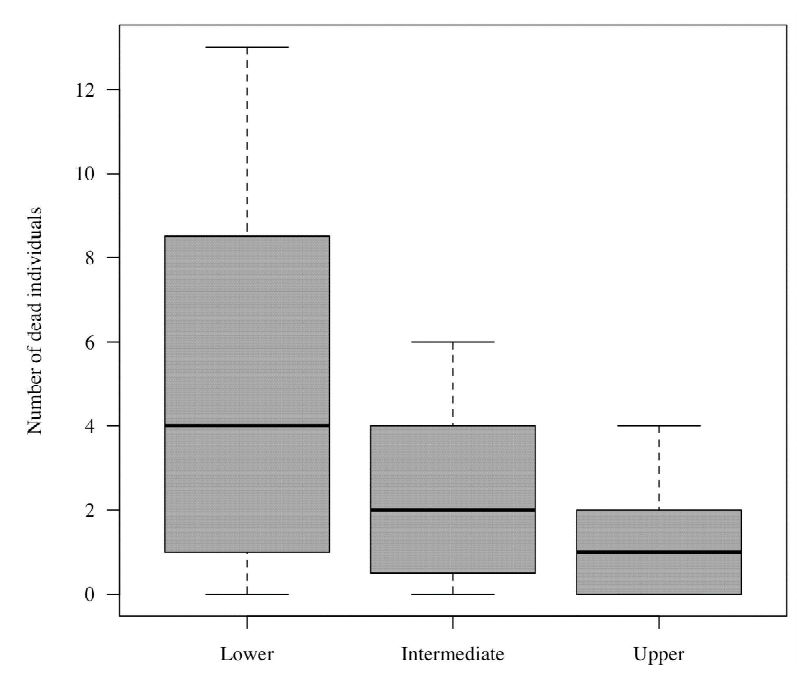

Figure 2 - Variation in the number of dead individuals per plots in each sector (Lower, Intermediate and Upper) in an ecotonal area between Mixed Ombrophilous Forest and Deciduous Seasonal Forest in the municipality of São José do Cerrito, SC, Brazil.

Figura 2 - Variação do número de indivíduos mortos por parcela de cada setor (Inferior, Intermediário e Superior) em uma área ecotonal de Floresta Ombrófila Mista e Floresta Estacional Decidual, São José do Cerrito, SC.

and Galvão (2011), sampling sufficiency has therefore been reached.

Regarding the Shannon index diversity value we have found $\left(\mathrm{H}^{\prime}=3.10\right)$, diversity can be considered from intermediate to high when compared to values found in other studies. According to Jarenkow and Budke (2009), several studies carried out in MOF areas from the southern and southeastern Brazil have indicated $\mathrm{H}^{\prime}$ estimates ranging from 2.25 to 3.54 nats.ind $^{-1}$. Souza et al. (2015) have found a lower value $\left(H^{\prime}=2.78\right)$ in a MOF and DSF transitional area. As for the result obtained for the Pielou evenness index $(\mathrm{J}=0.73)$, one can verify that the species ecological dominance is relatively intermediate. Jarenkow and Waechter (2001) have obtained a lower evenness value (0.56) in DSF therefore indicating high ecological dominance. In a transitional area, Souza et al. (2015) have obtained a similar value to the one we have found (0.67).

Allophylus edulis has stood out in the community, which may be mainly explained by the species' high density and frequency. However, the group of dead individuals and the large-sized Nectandra megapotamica and Araucaria angustifolia have shown the highest dominance, with a high basal area. The high importance of few species in contrast with the high occurrence of rare species is a common pattern in natural forests, as can be observed in other studies carried out in this region, such as the study in MOF areas by Silva et al. (2012) and the study in DSF areas by Jarenkow and Waechter (2001).

Considering that riparian areas are particularly sensitive to changes in the hydrological cycle being considered good indicators of environmental changes caused by dam reservoirs (Nilsson and Bergger, 2000), the high mortality of individuals, especially in the lower sector, is probably associated with its proximity to the dam water reservoir. These contact areas are exposed to new conditions of soil flooding with low availability of oxygen to the roots, therefore generating stress to non-adapted tree species (Nilsson and Bergger, 2000). Thus, it is inferred that one year after filling the reservoir it is possible to observe its interference in the community structure through the higher mortality in the lower sector.

As far as the spatial structuring of community organization is concerned, the plots spatially closer are also more similar from the floristic-structural point of view. However, such spatial structuring could not be associated with the reservoir distance sectors since the NMDS and the mvabund function have found no floristic-structural variations. There are possibly other ecological conditions that cause this spatial dependence pattern.

Thus, one can verify that structural changes have begun to occur one year after the reservoir filling and have been caused by variations in mortality among sectors. Yet there was not enough time for floristic changes to occur as they require a process over mortality time, which has already begun, along with the colonization of new species adapted to the new environmental conditions.

Such results are not in agreement with a similar study (Souza et al., 2015) carried out on the banks of a hydroelectric power plant's reservoir in an ecotonal forest area between MOF and DSF where variation in the floristic-structural composition along a topossequence adjacent to the reservoir has been observed. This differentiated pattern noticed by Souza et al. (2015) is probably due to a longer filling time of the reservoir, since their inventory was carried out eight years after reservoir filling.

Revista Árvore. 2017;41(3):e410317 


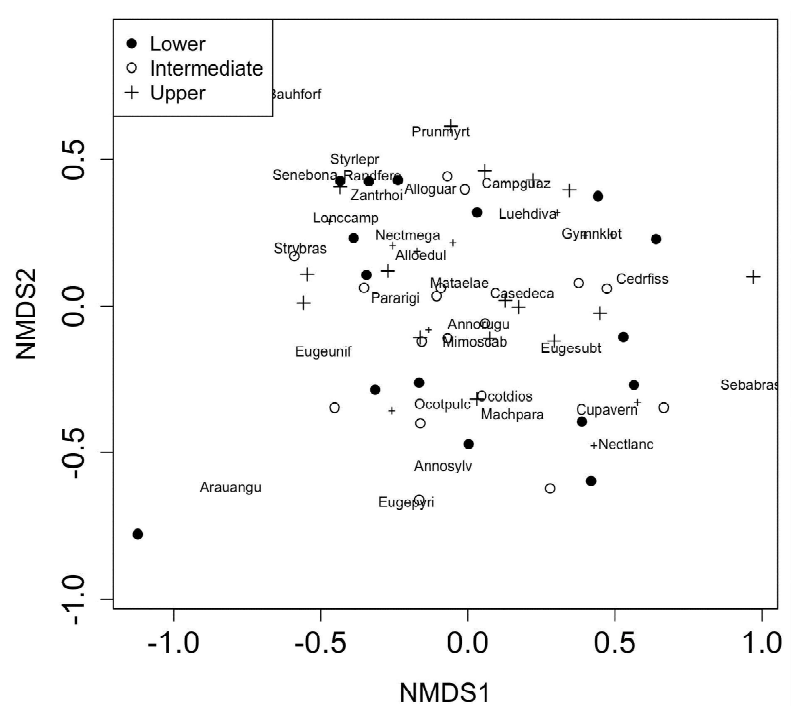

Figure 3-NMDS (Non-metric Multidimensional Scaling) ordination of plots and species sampled in an ecotonal area between Mixed Ombrophilous Forest and Deciduous Seasonal Forest in the municipality of São José do Cerrito, SC, Brazil.

Figura 3-Ordenação produzida pela NMDS (Escalonamento Multidimensional Não-métrico) das parcelas e espécies amostradas em um fragmento florestal de transição entre Floresta Ombrófila Mista e Floresta Estacional Decidual, em São José do Cerrito, SC.

\section{CONCLUSION}

It is worth noting the high representation of dead individuals, especially in the lower sector closer to the dam bed. This condition suggests an impact on the forest structure under the direct influence of the reservoir. There was no variation of the floristic-structural composition among sectors, though. Such condition may be due to the short period of time to the reservoir filling, where the environmental filter caused by the impact has not induced the expected changes therefore making it necessary to continue monitoring the vegetation dynamics over time in order to gauge possible changes in the community.

\section{ACKNOWLEDGEMENTS}

We thank to FAPESC for granting a scholarship to the first author of this paper and for the financial support granted through the PAP/UDESC; to CNPq for providing a research productivity grant to both the second and third authors; to Rio Canoas Energia for making the area available for study and for providing logistical support. We also thank the support offered by the landowners Marcos e Raquel Albuquerque.

\section{REFERENCES}

APG III. Angiosperm Phylogeny Group. An update of the Angiosperm Phylogeny Group classification for the orders and families of flowering plants: APG III. Botanical Journal of the Linnean Society. 2009;161(2):105-21.

Brower JE, Zar JH. Field and laboratory methods for general ecology. Dubuque: Wm. C. Brown Pub.; 1984. 226p.

Davide AC, Botelho SA, Faria JMR, Prado, NJS. Comportamento de espécies florestais de mata ciliar em área de depleção do reservatório da Usina Hidrelétrica de Camargos - Itutinga, MG. Cerne. 1996;2:20-40.

Empresa de Pesquisa Agropecuária e Extensão Rural de Santa Catarina - EPAGRI. Zoneamento agroecológico e socioeconômico do estado de Santa Catarina. Florianópolis: 1999. 1010p.

Empresa Brasileira de Pesquisa Agropecuária Embrapa. Solos do Estado de Santa Catarina. Rio de Janeiro: Embrapa Solos; 2004. 726p.

Fearnside PM. Environmental impacts of Brazil's Tucurui Dam: Unlearned lessons for hydroelectric development in Amazonia. Environmental Management. 2001;27(3):377-96.

Ferreira LV, Cunha DA, Chaves PP, Matos DCL, Parolin P. Impacts of hydroelectric dams on alluvial riparian plant communities in eastern Brazilian Amazonian. Anais da Academia Brasileira de Ciências. 2013;85(3):1013-23.

Herrera HAR, Rosot NC, Rosot MAD, Oliveira YMM. Análise florística e fitossociológica do componente arbóreo da Floresta Ombrófila Mista presente na Reserva Florestal Embrapa/Epagri, Caçador, SC - Brasil. Floresta. 2009;39(3):485-500.

Higuchi P, Silva AC, Ferreira TS, Souza ST, Gomes JP, Silva KM et al. Influência de variáveis ambientais sobre o padrão estrutural e florístico do componente arbóreo, em um fragmento de Floresta Ombrófila Mista Montana em Lages, SC. Ciência Florestal. 2012;22(1):79-90.

Revista Árvore. 2017;41(3):e410317 
Higuchi P, Silva AC, Almeida JA, Bortoluzzi RLC, Mantovani A, Ferreira TS. et al. Florística e estrutura do componente arbóreo e análise ambiental de um fragmento de Floresta Ombrófila Mista Alto-Montana no município de Painel, SC. Ciência Florestal. 2013;23(1):153-64.

Instituto Brasileiro de Geografia e Estatística IBGE. Manual técnico da vegetação brasileira. Rio de Janeiro: Instituto Brasileiro de Geografia e Estatística; 2012.271p.

Jarenkow JA, Budke JC. Padrões florísticos e análise estrutural de remanescentes florestais com Araucaria angustifolia no Brasil. In: Fonseca CSD editor. Floresta com Araucária: ecologia, conservação e desenvolvimento sustentável. Ribeirão Preto: Holus; 2009. p.113-26.

Jarenkow JA, Waechter JL. Composição, estrutura e relações florísticas do componente arbóreo de uma floresta estacional no Rio Grande do Sul, Brasil. Revista Brasileira de Botânica. 2001;24(3):263-72.

Junk WJ. Flood tolerance and tree distribution in central Amazonia. In: Holm-Nielsen LB, Nielsen IC, Balslev H, editores. Tropical forest botanical dynamics. London: Academic Press; 1989. p.47-64.

Kersten RA, Galvão F. Suficiência amostral em inventários florísticos e fitossociológicos. In: Felfili JM. editor. Fitossociologia no Brasil: métodos e estudos de casos. Viçosa, MG: Universidade Federal de Viçosa; 2011. p.153-76.

Klauberg C, Paludo GF, Bortoluzzi RLC, Mantovani A. Florística e estrutura de um fragmento de Floresta Ombrófila Mista no Planalto Catarinense. Biotemas. 2010;23:35-47.

Legendre P, Legendre LFJ. Numerical ecology. Amsterdam: Elsevier; 2012. 852p.

Muller-Dombois D, Ellenberg H. Aims and of vegetation ecology. New York: John Wiley \& Sons; $1974.547 \mathrm{p}$.
Myers N, Mittermeier RA, Mittermeier, CG, Fonseca GAB, Jennifer Kent J. Biodiversity hotspots for conservation priorities. Nature. 2000;403(6772):853-8.

Nilsson C, Berggren K. Alterations of riparian ecosystems caused by river regulation. Bioscience. 2000;50(9):783-92.

Oksanen J, Blanchet FG, Friendly M, Kindt R, Legendre P, McGlinn D et al. Vegan: Community ecology package. [acessado em: 11 nov. de 2014]. Disponível em: http://cran.r-project.org/

R Development Core Team. R: A language and environment for statistical computing. [acessado em: 11 nov. de 2014]. Disponível em: http://www.rproject.org/

Silva AC, Higuchi P, Aguiar MD, Negrini M, Fert Neto J, Hess AF. Relações florísticas e fitossociologia de uma Floresta Ombrófila Mista Montana Secundária em Lages, Santa Catarina. Ciência Florestal. 2012;22(1):193-206.

Souza K, Souza CC, Rosa MG, Cruz AP, Lima CL, Silva JO et al. Estrutura e estratégias de dispersão do componente arbóreo de uma floresta subtropical ao longo de uma topossequência no alto-uruguai. Scientia Forestalis. 2015;43(106):321-32.

Wang Y, Naumann U, Wright, ST, Warton DI. Mvabund-an R package for model based analysis of multivariate abundance data. Methods in Ecology and Evolution. 2012;3(3):471-4.

Wang Y, Naumann U, Wright T, Eddelbuettel D, Warton D. Mvabund: statistical methods for analysing multivariate abundance data. $\mathrm{R}$ package version 3.9.3. [acessado em: 11 nov. de 2014]. Disponível em: http://CRAN.R-project.org/ package $=$ mvabund

Zuur A, Leno EN, Walker N, Saveliev AA, Smith GM. Mixed effects models and extensions in ecology with R. Amsterdam: Springer Science \& Business Media; 2009. 574p. 